\title{
Editorial
}

\section{COVID-19 en aguas residuales y potables: análisis de la situación actual}

El siguiente análisis pretende mostrar el panorama actual a nivel mundial relacionado con la presencia del Covid-19 en aguas residuales y potables. Muestra información recopilada de organismos oficiales o adaptados de estudios de investigación que se están llevando a cabo actualmente.

$\mathrm{Al}$ inicio de la pandemia, en Europa un grupo de científicos holandeses del Instituto de Investigación del Agua KWR encontraron rastro del coronavirus en las aguas residuales de una ciudad de Países Bajos antes de que se informaran de los casos de Covid-19. A partir de este momento se ha iniciado una carrera por parte de muchos centros de investigación y empresas del ciclo integral del agua, orientada a demostrar que el virus no está activo en las aguas residuales y potables. Desde el KWR, los científicos aseguran que "el agua potable está muy bien protegida contra todos los virus, incluido el nuevo coronavirus". Es importante resaltar que el agua no está listada como una de las vías de transmisión del virus que recoge la Organización Mundial de la Salud (OMS).

Por otra parte, en Marzo del presente año la Agencia de Protección Ambiental (EPA) emitió un comunicado expresando que el virus COVID-19 no ha sido detectado en el suministro de agua potable. Conforme a la evidencia actual, es bajo el riesgo para el suministro de agua.

Además, la Organización Mundial de la Salud, la Agencia de Protección Ambiental de Estados Unidos (EPA), los Centros para el Control y la Prevención de Enfermedades de Estados Unidos (CDC) y el Ministerio de Sanidad de nuestro Estados Unidos no dudan en asegurar que el consumo de agua potable es totalmente seguro.

En otro comunicado, biólogos ambientales de la Universidad de Stirling (Reino Unido) han advertido de que la posible propagación del Covid-19 a través de las aguas residuales "no debe ser descuidada" en la batalla para proteger la salud humana. La respuesta a la pandemia mundial se ha centrado en la prevención de la transmisión de persona a persona, sin embargo, los expertos creen ahora que el virus también podría propagarse en las aguas residuales.

En España, más de una veintena de centros de investigación, empresas del sector del agua y administraciones públicas han puesto en marcha diversos proyectos con el objetivo de identificar la presencia del covid-19 en diversas fuentes hídricas entre las que se incluyen las aguas residuales y las aguas potables.

Las investigaciones que se están desarrollando plantean la posibilidad de utilizar las aguas residuales como centinelas de la pandemia, ya que es posible medir la presencia del virus en aguas residuales y relacionarlas con el número de infectados en determinadas zonas. Varias ciudades españolas ya han empezado con estos estudios, ya que como afirman los expertos estas investigaciones "permiten analizar la carga viral presente en las aguas residuales y lodos de las plantas de tratamiento de aguas residuales y conocer la evolución real de la epidemia, ya que recoge datos de toda la población, incluyendo personas que hayan pasado el COVID-19 sin saberlo". 
Los primeros resultados que se están llevando a cabo en España (Región Murcia, Valencia, Navarra, Barcelona y Madrid) muestran que se ha confirmado "la presencia de material genético de SARS-CoV-2 en la red de alcantarillado, el reto actual es identificar la integridad del virus y su capacidad infecciosa, ya que todo parece indicar que el virus se inactiva y las células se rompen en los colectores antes de que el virus entre a la planta de tratamiento".

En este sentido, investigadores del Consejo Superior de Investigaciones Científicas (CSIC) en España y la Universidad de Valencia han desarrollado un sistema de análisis molecular que puede alertar de la circulación del coronavirus Covid-19 en las aguas residuales. El sistema de análisis puede ser útil como método de vigilancia epidemiológica. Los análisis han demostrado que los tratamientos de desinfección en las depuradoras son eficaces en la eliminación de la presencia del virus. Tras analizar el agua en varias plantas de tratamiento de la Región de Murcia y el área metropolitana de Valencia en España, sus mediciones han detectado la presencia de material genético de SARS-CoV-2, demostrando, según los investigadores, que los tratamientos de desinfección en las plantas de tratamiento «son eficaces》 en la eliminación del virus.

Los diversos resultados obtenidos en diversas zonas de Europa muestran que las aguas que llegan a las plantas de tratamiento de agua residual contienen ARN del SARS-CoV-2, pero las que salen ya depuradas están completamente limpias, gracias a las tecnologías de desinfección con las que cuentan estas instalaciones. Aunque no se han hecho pruebas de viabilidad, es "improbable" afirman algunos expertos, que el ARN viral que queda en las aguas fecales sean virus con capacidad de infectar, sino más bien fragmentos que no pueden causar enfermedad.

Las investigaciones realizadas hasta el momento respecto a la presencia del COVID-19 en aguas residuales van más allá y pretenden aparte de determinar la presencia y viabilidad del virus, es incorporar herramientas de análisis metagenómico, big data e inteligencia artificial para integrar los resultados de los análisis en aguas, con diversos datos sanitarios, climatológicos o los que se consideren relevantes para monitorizar y discriminar la información relevante en la toma de decisiones que permitan alertar sobre posibles rebrotes.

Esta integración de tecnología permitirá anticiparse a algunos de los indicadores al uso y cruzar los datos con otros que recopilan las instituciones sanitarias para sumar información y hacer un mapa general de la progresión o del retroceso de la pandemia en diferentes regiones.

Todo estos estudios tiene sentido cuando existen redes de saneamiento y plantas de tratamiento en las ciudades, que permitan hacer un seguimiento eficaz del virus a través de los colectores y las plantas de tratamiento. En Colombia, aunque cada vez existe más inversión en infraestructuras hidráulicas, existe una carencia importante de estas instalaciones que imposibilita la implementación de estudios de este tipo. Las aguas residuales producidas en muchas regiones de Colombia, son enviadas a los medios receptores como ríos, mares y lagos sin ningún tipo de tratamiento.

"Lo que sabemos es una gota de agua; lo que ignoramos es el océano" Isaac Newton

Javier Eduardo Sánchez Ramírez PhD Ingeniero Químico, ambiental y de Procesos Investigador Externo Universidad Surcolombiana

Miembro del comité editorial 